\title{
ANALYSIS OF WAITING TIME FOR PHARMACEUTICAL SERVICES CEMPAKA PUTIH HOSPITAL
}

\author{
Ferti Dwi Ekasari, Adang Bachtiar
}

Faculty of Public Health, Universitas Indonesia

\begin{abstract}
Background: With the increasing public awareness of the importance of the health of the services and excellent health services become indispensable by the community to meet the demand for health especially pharmaceutical services in support of optimal health system. In order to give satisfaction to the patient, the pharmacy service becomes one of the factors that affect the realization of the objectives of the policy making. The quality of services as a measure of how good a given level of serviceable to match the expectations of patients. Quality of services is an advantage that is perceived by the consumer services of the comparison between what customers want with what is acceptable to the consumer after the purchase of services. This study aimed to analyze of waiting time for pharmaceutical services Cempaka Putih Hospital.

Subjects and Method: This was a quasi experiment before and after with no control design conducted at Cempaka Putih Hospital on 1 August 2017 to 30 September 2017. A sample of several patients in the queue at the pharmacy was selected by systematic random sampling. The dependent variable was waiting time. The independent variable was effort to improve pharmaceutical service quality, including improved service flow, centralize pharmacies, arrange pharmacy, create programs between cashiers and pharmacy, make etiquette with programs, and socialize doctors about writing well and correct recipes. The data were collected by questionnaire and tested by by t-test.

Results: The average of waiting time for pharmaceutical services was faster after intervention (12 minutes) than before (24 minutes) and it was statistically significant.

Conclusion: Effort to improve pharmaceutical service quality has successfully decreased waiting time for pharmaceutical service less than 30 minutes of Minimum Service Standards.
\end{abstract}

Keywords : waiting time, pharmaceutical services, minimum Service Standards.

Correspondence:

Ferti Dwi Ekasari. Faculty of Public Health, Universitas Indonesia.

Email: fertydwi@gmail.com. Mobile: +6281510303716.

\section{BACKGROUND}

The hospital as one of the providers of health services is required to provide quality health services to the community. According to Law of the Republic of Indonesia Number 44 of 2009 concerning Hospitals stated that the Hospital is a health service institution that organizes individual health services comprehensively that provides inpatient, outpatient and emergency services. Plenary health services are services that are expected to provide maximum hospital patient satisfaction according to established standards. There are many ways to improve patient satisfaction in getting services at the hospital, one of which is to accelerate waiting time in getting services at the hospital.

Service waiting time is the length of time needed by patients ranging from registering to getting services. Patient satisfaction with a hos- 
pital is determined by the waiting time. Patient waiting time is one component that has the potential to cause dissatisfaction that has an impact on the quality of service in a hospital. It is understandable that patients who go to the hospital are people with conditions that are uncomfortable in their body, so they hope to get service as soon as possible to eliminate the illness they suffered during a visit to the hospital.

Hospital management sometimes still ignores the length of waiting time while almost the majority of patient complaints at the hospital are about the length of service waiting time.

Cempaka Putih Hospital tries to make quality improvements by identifying problems at the Hospital by the Quality Control Circle (QCC) team. The Cempaka Putih Hospital QCC team found that the priority of the problem was the length of the waiting time for pharmaceutical services.

According to the Decree of the Minister of Health of the Republic of Indonesia Number 1197 Years 2004 stated that pharmaceutical services are an inseparable part of the hospital's health care system that is intact and oriented to patient services, providing quality medicines, including clinical pharmacy services that are affordable for all levels of society.

The length of waiting time for pharmaceutical services can provide several risk effects including contracting the disease (nosocomial infection, upper respiratory tract infections, and tuberculosis) from other patients, delay in taking medication, reducing patient rest time, increasing patient complaints, and decreased patient satisfaction and reduced number of hospital patient visits.

\section{SUBJECTS AND METHOD \\ 1. Study Design}

This was a quasi-experiment before and after with no control design conducted at the Cempaka Putih Hospital, Jakarta, on 1 August 2017 to 30 September 2017.

\section{Population and Samples}

A total of 352 patients was selected by systematic randomly sampling. The population in this study was patients of Cempaka Putih Hospital pharmacy services.

\section{Study Variables}

The dependent variable was waiting time. The independent variable was effort to improve pharmaceutical service quality including improve service flow, centralize pharmacies, arrange pharmacy, create programs between cashiers and pharmacy, make etiquette with programs, and socialize doctors about writing good and correct recipes.

\section{Definition of Variables}

The waiting time for pharmaceutical services defined by the length of the service waiting time since the patient submitted the prescription to the pharmacy department until the patient gets the medicine.

Efforts made in improving the quality of pharmaceutical services were done by improving the service flow, arranging pharmacies, making programs between cashiers and pharmacies, making etiquette with the program, and socializing doctors about good and correct prescription writing. 


\section{Study Instrument}

The instrument in this study used to daily wait time observation sheet and questionnaire.

\section{Analysis Data}

Analysis data we're using a Mann Whitney test with groups before and after intervention.

\section{RESULTS}

There was a significant difference in non-compound medicine waiting time $(p<0.001)$ between before and after the intervention. Where the noncompound medicine waiting time is obtained before the longer intervention is carried out with a mean value of 25 (10 to 58 ) compared to after the Intervention with a mean value of 15 ( 2 to 44 ) (Table 1 ).

The compound medicine waiting time is obtained before the Intervention takes longer with the middle value 11 ( 2 to 40 ) compared to after the intervention with the middle value 7 (1 to 27) (Table 2).

Table 1. Comparison of waiting times for non compound medicine before and after intervention.

\begin{tabular}{lccccccc}
\hline & N & Mean & Median & Minimum & Maximum & SD & p \\
\hline Before & 176 & 24.36 & 25 & 10 & 58 & 7.26 & \\
After & 176 & 15.34 & 15 & 2 & 44 & 5.88 & $<0.001$ \\
\hline
\end{tabular}

Table 2. Comparison of waiting times for compound medicine before and after intervention

\begin{tabular}{lccccccc}
\hline & N & Mean & Median & Minimum & Maximum & SD & p \\
\hline Before & 176 & 12.34 & 11 & 2 & 40 & 6.32 & \multirow{2}{*}{0.001} \\
After & 176 & 8.14 & 7 & 1 & 27 & 4.97 & \\
\hline
\end{tabular}

\section{DISCUSSION}

Render et al (2009) in Dhiyanto (2014) stated that waiting time is defined as people or goods in the line waiting to be served, for example patients who are waiting in a pharmaceutical service unit. The Ministry of Health through Minimum Service Standards has set a waiting time in Indonesia. All hospitals in Indonesia must appropriate the Minimum Service Standards regarding this waiting time.

The waiting time for prescription services is divided into two, namely the waiting time for prescription services for finished or compound medically and the waiting time for non-compound medicine.

According to the Decree of the Minister of Health of the Republic of Indonesia Number 129/Menkes/SK/II/2008 about Hospital Minimum Service Standards explained that the waiting time for non-compound medical services is a period of time for patients to submit prescriptions to receive non compound medicine. While the waiting time for compound medicine service is a time period for patients to submit prescriptions to receive compound medicine. According to service standards Minimum waiting time for pharmaceutical services 
for compound medicine is $\leq 30$ minutes, while for the non-compound medicine is $\leq 60$ minutes.

In this study the number of samples studied was 352 samples with 88 samples with the same number for compound and non-compound medicine each month during November 2017 to February 2018.

\section{The average waiting time for compound medicine pres- cription services before be- ing given an intervention.}

The average waiting time for compound medicine prescription services before being given an intervention is 12 minutes, where these results meet the standard time set by the SPM which is equal to 15 minutes. Whereas the average waiting time for non-compound medicine recipes before being given intervention in that month is 24 minutes, where this result also meets the standard waiting time set by the SPM which is equal to 30 minutes.

The Quality Control Circle (QCC) team at Cempaka Putih Hospital is trying to make improvements to increase customer satisfaction in the pharmaceutical services of Cempaka Putih Hospital. Efforts made including improving the flow of services, centralizing pharmacies, structuring pharmaceuticals, making programs between cashiers and pharmacies, making etiquette with programs, and socializing doctors regarding good and correct prescription writing.

\section{Factors that caused longer waiting time for medicine prescription}

Based on observations in the field, it is known that the causes of the long waiting time of Cempaka Putih Hos- pital pharmacy services include:

a. The prescription is unclear and incomplete, so the pharmacist must confirm to the doctor

b. Pharmacists must price each recipe, because the cashier has no data on drug prices

c. The flow of the old service, the patient is required to go to the pharmacy then the cashier then to the pharmacy again

d. A separate pharmacy room on the 1st floor and on the 3rd floor so that medicines are also separate

e. Drugs are difficult to find due to the narrow and unorganized pharmaceutical rooms

f. Tagging etiquette manually.

According to Yulianthy (2011) Inadequate computerized systems, especially for prescription services at the reception point of prescriptions and lack of room facilities, especially in the reception and delivery room, so it is rather difficult to add personnel if needed at rush hour. Because the incompatibility of waiting time for prescription services with SPM in each type of prescription has differrent causes.

For prescription service waiting time, the factors that cause the longer prescription service are found in the etiquette process (Pipintri and Irmawati, 2017). The time needed in the etiquette process can be longer because the etiquette officer must write the rules for using the drug in accordance with the prescription for filling in the patient's drug record card, this is almost in accordance with the problems that occur in Cempaka Putih Hospital. 


\section{An Effort to improve phar- maceutical service quality}

Based on the above causes, Cempaka Putih Hospital conducts intervention or improvement efforts including:

a. Conduct socialization with interactive slides and frequently asked questions related to good and correct prescription writing

b. Connecting the pharmacy and cashier with the computer program so it can eliminate the waiting time for drug calculations

c. Improving the Service Flow so it can to eliminate the waiting time for payment at the checkout

d. Arranging medicines in alphabetical order, dosage forms in pharmaceuticals and pharmaceutical warehouses using small boxes so it can speed up the average time for taking concoction drugs

e. Centralizing pharmacies that were on two different floors became on the same floor and expanded the pharmaceutical space

f. Speed up the manufacture of etiquette that was originally manual by using the program so that it can print etiquette directly within 2 minutes.

After several attempts to improve pharmaceutical services, the researchers tried to calculate the average waiting time after intervention. Data obtained from the average waiting time for compound medicine prescription services after being given an intervention in January and February 2018 was to be 8 minutes, which successfully decreased the waiting time by 4 minutes. While the average non compound medicine waiting time after giving the intervention for the month was 15 minutes, which managed to decrease the waiting time by 9 minutes.

Based on the results of the Mann Whitney Test, the differrence in waiting time for compound and non-compound medicine was significant ( $p<0.05$ ) between before and after the intervention.

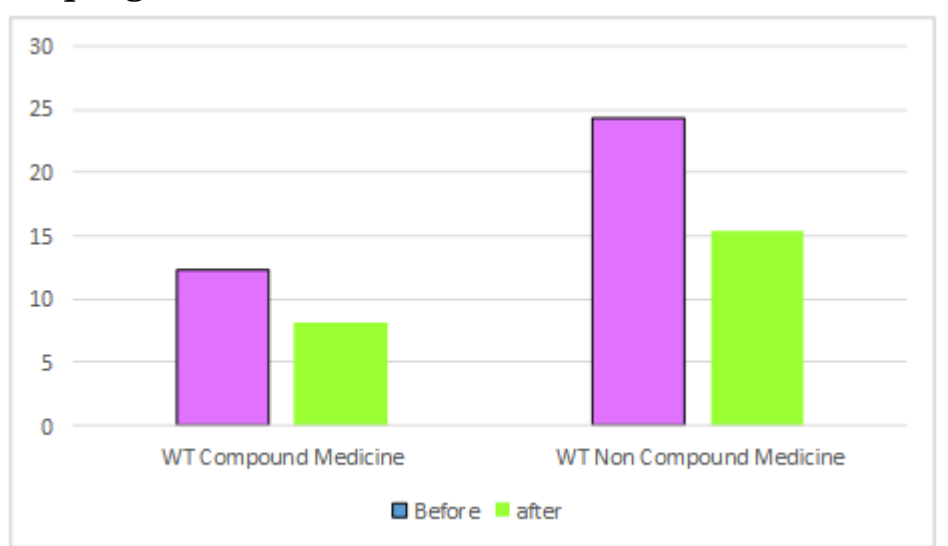

Figure 1. Comparison of the average WT of compound and noncompound medicine before and after the intervention 
Table 3. Evaluation of the efforts to improve pharmaceutical services

\section{Evaluation}

\begin{tabular}{ll}
\hline Quality & $\begin{array}{l}\text { The average waiting time for a pharmaceutical installation deviates } \\
\text { from o\% (January } 2018 \text { - February 2018). }\end{array}$ \\
Cost & Pharmacy service revenue has increased in February 2018 \\
Delivery & The average number of recipes that can be served by each pharmacist \\
& has doubled in 24 hours \\
Healthy & The time needed by pharmacists to service all infectious disease \\
& patients can be faster so that they can reduce the amount of disease \\
& transmission \\
Morale & The pharmacy service satisfaction rate has increased to $90.95 \%$ after \\
& intervention from the before $79.7 \%$
\end{tabular}

Based on data analysis, it can be concluded that the intervention efforts that have been carried out such as improving service flow, arranging pharmacies, making programs between cashiers and pharmacies, making etiquette with programs, and socializing doctors about good and correct prescription writing have significantly reduced the waiting time of pharmaceutical services. Waiting time for patient service is one indicator of patient satisfaction with the quality of hospital services. The success of the pharmacy service waiting time also contributes to the satisfaction of Cempaka Putih Hospital patients, thus creating continuous quality improvement. It is hoped that continuous quality improvements can be carried out by all hospitals in Indonesia.

\section{REFERENCE}

Dhiyanto H (2014). Hubungan Waktu Tunggu Periksa dan Pemberian Informasi terhadap Kepuasan Pasien Rawat Jalan (False Emergency) pada Pelayanan Di Instalasi Gawat Darurat RS Emanuel Purwareja Klampok Banjarnegara. Fakultas Ilmu Kesehatan UMP. Purwokerto.
Keputusan Menteri Kesehatan Republik Indonesia Nomor 129 Tahun 2008. Tentang Standar Pelayanan Minimal Rumah Sakit. Jakarta.

Keputusan Menteri Kesehatan Republik Indonesia Nomor 1197 Tahun 2004. Tentang Standar Pelayanan Farmasi di Rumah Sakit. Jakarta.

Laeliyah N, Subekti H (2017). Waktu tunggu pelayanan rawat jalan dengan kepuasan pasien terhadap pelayanan di rawat jalan RSUD Kabupaten Indramayu. Jkesvo (Jurnal Kesehatan Vokasional), 1(2).

Lintang MG, Maramis FRR, Rumayar AA (2017). Hubungan antara waktu tunggu pelayanan resep dengan kepuasan pasien di instalasi farmasi rumah sakit umum pancaran kasih manado. Fakultas Kesehatan Masyarakat Universitas Sam Ratulangi. Manado.

Margiluruswati P, Irmawati LI (2017). Analisis ketepatan waktu tunggu pelayanan resep pasien $\mathrm{JKN}$ dengan standar pelayanan minimal rumah sakit 2017 (Studi di UPF Rawat Jalan RSUD Bhakti 
Dharma Husada). Jurnal Manajemen Kesehatan Yayasan RS Dr. Soetomo, 3(2): 115 - 126. Peraturan Menteri Kesehatan Nomor 73 Tahun 2016 tentang Standar
Pelayanan Kefarmasian di Apotek. Jakarta.

Undang-Undang Republik Indonesia Nomor 44 Tahun 2009 tentang rumah sakit. Jakarta. 